\title{
Protected Black and Acadian Electoral Districts in Nova Scotia: A case-study in institutionalised surrogate representation
}

\author{
Author: Michael J. Wigginton \\ PhD Candidate, School of Political Studies, University of Ottawa, Room FSS7005, 120 University \\ Private, Ottawa ON K1N 6N5, email: michael.wigginton@uottawa.ca
}

This is a post-peer-review, pre-copyedit version of an article published in the British Journal of Canadian Studies. The final version appears in issue 33:1 and is available online at: https://doi.org/10.3828/bjcs.2021.4

Please do not cite this version.

Date: November 2020

\begin{abstract}
From 1991-2011, the political representation of the Acadian and Black populations of Nova Scotia was ensured via four 'protected ridings'; electoral districts with population sizes well below median size created for their significant minority presence, a unique initiative that remains little-examined in the literature. Through the reports of the electoral boundaries commissions, I examine the models of representation implicit in this system and use them to further the definition of surrogate representation presented by Jane Mansbridge, finding that what emerged was a system of institutionalised surrogate representation, wherein Acadians and African Nova Scotians throughout the province were represented by the representatives of the protected ridings. Beyond providing an overview of the unique Nova Scotian case, this paper also furthers the literature on surrogate representation by demonstrating that surrogate representation can be sub-divided into two forms, which I categorize as 'promissory/anticipatory surrogate representation' and 'gyroscopic surrogate representation'.
\end{abstract}

Key words: Nova Scotia, Acadians, Surrogate Representation, Protected Ridings, Descriptive Representation

RÉSUMÉ: De 1991 à 2011, la représentation politique des populations acadiennes et noires de la Nouvelle-Écosse a été assurée par quatre 'circonscriptions protégées', des circonscriptions électorales dont la population est bien inférieure à la taille médiane et qui ont été créées pour leur importante présence minoritaire, une initiative unique qui reste peu étudiée dans la littérature. À travers les rapports des commissions de délimitation des circonscriptions électorales, j'examine les modèles de représentation implicites dans ce système et je les utilise pour approfondir la définition de la représentation de cause (surrogate representation) développé par Jane Mansbridge, en constatant que ce qui en est ressorti est un système de représentation de substitution institutionnalisé, dans lequel les Acadiens et les Afro-Néo-Écossais de toute la province étaient représentés par les représentants des circonscriptions protégées. En plus de fournir un aperçu du cas unique de la Nouvelle-Écosse, cet article fait également avancer la littérature sur la représentation de substitution en démontrant que la représentation de substitution peut être subdivisée en deux formes, que je catégorise comme 'représentation de cause promissoire/anticipatoire' et 'représentation de cause gyroscopique'.

Mots clés: Nouvelle-Écosse, Acadiens, Représentation de cause, Circonscriptions protégées, Représentation descriptive 


\section{Introduction}

In July of 1991, the government of Nova Scotia parted with its history of politically created electoral boundaries and opted to create an independent and non-partisan provincial electoral boundaries commission to advise the government in creating new districts, commonly called 'ridings' (Hyson 1995: 285). In addition to distancing the re-districting process from partisan politics, the creation of the 1991 commission also brought with it a major focus on minority representation. The terms of reference created to guide the commission made explicit reference to drawing boundaries in a way that represents the Acadian and African Nova Scotian ${ }^{2}$ communities of the province, and the Orderin-Council creating the committee also called for an additional seat to be created to represent the Mi'kmaq people (Executive Council of Nova Scotia 1991). Similar terms were used to guide the 2002 commission and the ridings were retained unchanged. While the 2012 Commission's report led to the districts being abolished, the 2019 Commission has recommended they be restored.

In the process of their creation, in the debates surrounding their abolition, in the twenty years of their existence, and in the reports recommending their return, little explicit consideration was given as to how exactly these four ridings would represent the Acadian and African Nova Scotian communities. What concept of representation allowed these districts to provide representation, and what lessons does the Nova Scotian experience hold for scholars of representation? In this article I will argue that despite the lack of much explicit acknowledgment, these districts were intended to provide representation to all African Nova Scotians and Acadians in the province, not just those who resided in the districts, using a form of surrogate representation. This form of representation can be found in the institutional features of the ridings as well as how they were justified by those in government. I will further argue that this model of surrogate representation produced took two different forms to different observers, which I refer to as 'Promissory/Anticipatory Surrogate Representation' and 'Gyroscopic Surrogate Representation', expanding upon on the work of Jane Mansbridge.

To do this, I will first present a brief summary of the concept of surrogate representation, as well as a brief overview of the concept of protected ridings. I will then compare Nova Scotia's protected ridings to other similar projects, to highlight some of their more unique features, and then use examples from the reports of the Boundaries Commissions to demonstrate the surrogate representation inherent to them. Finally, illustrated by examples from debates House of Assembly, I present the two distinct conceptualisations of surrogate representation that can be used to explain how these districts served to further representation of Acadians and African Nova Scotians.

\section{Surrogate Representation}

Surrogate representation is, as defined by Jane Mansbridge, 'representation by a representative with whom one has no electoral relationship - that is, a representative in another district' (Mansbridge 2003: 522). In general, according to Mansbridge, surrogate representation occurs when a particular issue, concern, or group is not sufficiently concentrated in District A to have gained representation in the legislature, so instead constituents of District A are represented via District B where the concentration is greater (Mansbridge 2003: 523). Despite Mansbridge's American focus, surrogate 
representation can arise in proportional systems as well; Manon Tremblay argues that female representatives can serve as surrogate representatives for women, with an emphasis on proportional systems where women can achieve the 'critical mass' that Tremblay argues is necessary for a substantive representation (Tremblay 2006). For both authors, however, surrogate representation is presented as being an ad-hoc phenomenon; even in Tremblay's examples, where proportional systems tend to favour representation of women either through the inherent qualities of the system or through a quota system, Tremblay argues that surrogate representation further requires that female parliamentarians 'commit themselves to representing women' (Tremblay 2006: 507). Although her conception too is ad-hoc, Mansbridge does not view a conscious commitment as a necessity, arguing that surrogates may play their role 'unconsciously ... [or] simply by chance' (Mansbridge 2011: 628).

Surrogate Representation is a distinct, yet related notion to that of mirror or descriptive representation - that is to say the idea that legislators ought to be 'in some sense typical of the larger class of persons whom they represent,'(Mansbridge 1999: 629) generally in terms sharing the same gender, religious or ethnic identity. Although Mansbridge argues this makes the surrogate relation stronger, particularly in cases where few members of their group are present in the legislature, (Mansbridge 2003: 523) 'surrogate representatives do not have to be descriptive representatives' (Tremblay 2006: 507). Indeed, Mansbridge invokes many examples of surrogate representation on non-identitary issues, such as anti-war representatives representing those anti-war citizens who have pro-war representatives (Mansbridge 2003: 523).

\section{Protected Ridings: A brief overview and history}

In 1991 the Supreme Court of Canada delivered their split Carter decision, in which the majority opinion found large variations in district population to be justified under the Charter of Rights and Freedoms, and further found that electoral boundaries should be created to ensure effective representation, possibly requiring deviations based upon factors such as history and minority representation (Reference re Prov. Electoral Boundaries (Sask.) 1991). In the same year, Nova Scotia created its first independent boundaries commission to handle re-districting, in response to both Carter and broader societal pressure for reform (Hyson 1995: 290). As such, the 1992 commission was given terms of reference that explicitly called upon it to consider the representation of the provinces' Black and Acadian communities.

As a result of the decisions of the first boundaries commission, from 1992-2012, four ridings ${ }^{3}$ were considered to be 'protected' due to their particular ethno-linguistic composition. The notion of protection in this case is that they were exempted from the population requirements that other ridings would be held to, and thus allowed to have populations far below the provincial median; while districts generally are required to have a population within $25 \%$ of the median population, these districts were exempted from that calculation. For example, in 2002 the smallest district (Clare) had a population of only 8,019, while the largest district (Bedford-Birch Cove) had a population of 32,743 (Keefe 2017: 193). In all other senses they were entirely ordinary ridings - they each elected a single MLA (Member of the Legislative Assembly) ${ }^{4}$ to the House of Assembly as did all other 
districts, using the same single member plurality system. It is worth noting that these ridings were not gerrymandered, in the sense that they did not have particularly convoluted or arbitrary boundaries. The three Acadian ridings were in fact pre-existing and followed the boundaries of existing Municipalities of Clare and Argyle and of the County of Richmond. Though it was a creation of the 1992 Commission, Preston mostly corresponded to the boundaries of two neighbouring districts in the Municipality of the County of Halifax and is generally thought to be a cohesive community.

Following a far more controversial process than the previous two Boundaries Commissions, which saw Commission members resign and received seemingly universal disapproval from the opposition parities, (Nova Scotia 2012) Darrel Dexter's NDP government passed Bill 94 and merged the four previously protected ridings in with their majority white and anglophone neighbours. The resulting districts substantially reduced the percentage of francophone voters, and saw fewer Acadians elected (Deschênes-Thériault 2018). In a reference case, the Nova Scotia Court of Appeal delivered an opinion finding the process through which the protected ridings were abolished to be unconstitutional (Reference re the Final Report of the Electoral Boundaries Commission 2017), and the Commission on Effective Electoral Representation of Acadian and African Nova Scotians (which had been struck in response to the reference case) delivered a report that was friendly to the return of some form of protected ridings, but also considered many other solutions (Commission on Effective Electoral Representation 2017). Having been given looser terms of reference than its 2012 predecessors, the 2019 Commission ultimately recommended that the House of Assembly be expanded to 55 seats, but also that the four protected ridings be restored, although in slightly modified forms. As their report has been enacted into law, the next general elections will see these districts re-created. ${ }^{5}$

\section{Comparison to other similar projects}

While united in their goal of representing ethnic minority groups, the protected African Nova Scotian and Acadian ridings are nevertheless distinct from other attempts to ensure minority representation through special districts seen in other jurisdictions. New Zealand and The United States have both enacted programmes that are similar to that seen in Nova Scotia, while differing in some key respects. In this section I will contrast the protected ridings to these three other attempts to ensure minority representation through electoral districts, in order to both better explain their features and to highlight their surrogate nature.

\section{New Zealand's Māori districts}

Since 1867, New Zealand has allowed their indigenous Māori population to vote in separate electorates that overlap with the general electorates in which non-Māori vote. Originally, Māori were only permitted to vote in their own electorates, but in modern times Māori electors can chose to enroll to vote in either their general or their Māori electorate. Both the Māori and general electorates are elected using a single member plurality system, even following the adoption of Mixed-Member Proportional Representation for the country's Parliament (Fleras 1985; Banducci, Donovan, and Karp 2004; Geddis 2006). 
Obviously, the Nova Scotian programme of minority representation is different from that of New Zealand in several demographic respects. Whereas New Zealand's system aims to ensure representation for a single, large national minority (the Māori make up around $16 \%$ of the population), Nova Scotia's system was designed to favour two distinct groups both of which make up rather small percentages of the population (about 3.8\% for Francophones (Statistics Canada 2012) and 2.2\% for African Nova Scotians(Statistics Canada 2015)). As an indigenous people, the nature of Māori representation within the New Zealand Parliament is also different in nature than representing Acadians or African Nova Scotians, and more similar in its aims to the proposals for a Mi'kmaq seat. Moreover, the institutional structures of the two systems are significantly different. Whereas as Māori in all regions of New Zealand can vote in special Māori electorates that overlap with the general electorates - that is to say that every New Zealander lives within the boundaries of both a general and a Māori electorate - only those Acadians living in Clare, Argyle and Richmond, and those African Nova Scotians living in Preston, could vote in the 'Acadian' and 'A frican Nova Scotian' ridings. As a natural consequence, the Māori electorates contain only Māori electors, whereas the protected ridings contained either a large minority or indeed a majority of citizens outside the community of interest. Additionally, whereas Nova Scotia's protected ridings are permitted to have significantly smaller populations than average, New Zealand's Māori electorates are kept in rough proportion to the number of people enrolled on the Māori electoral roles, and as such the number of Māori electorates has changed several times (Vowles 2005: 300).

The chief difference then is that all Māori electors (or at least all Māori electors who chose to register on the Māori rolls) have a direct, formal link with their designated Māori representatives, whereas many Acadians have no capacity to influence the choice of 'Acadian Representatives' in the House of Assembly. The result, then, is a form of surrogate representation for many Acadian and African Nova Scotians, as opposed to the direct representation for the Māori who wish to have it. The Māori Members of Parliament thereby also have a clearer role, as they represent only Māori constituents, whereas MLAs in the protected ridings represent citizens of various ethnolinguistic identities.

In both the Keefe Report and the 2019 Final Report, the most recent Commission explicitly considered the New Zealand's model. In one proposal the commission considered a limited system wherein Acadian electors in the Chéticamp aera would be able to chose to vote either for a traditional MLA or for a reserved Acadian seat for the district (Dodds 2019: 92-93). In others, a province-wide system more akin to New Zealand would be implemented, allowing Acadian electors to chose to vote in an at-large district. While similar proposals have been considered for Nova Scotia since as early as the 2012 Commission, they have been consistently rejected on both practical and philosophical grounds. Practically, Commissions have expressed doubts as to the feasibility of maintaining a separate register of electors, as well as concerns that relatively few would opt to vote these at-large districts, and that most would continue to vote in their geographic district. The comparatively small populations of African Nova Scotians and Acadians also pose a practical barrier (Keefe 83-84). Philosophically, the Keefe report also raised the possibility a system like New Zealand's would over-emphasise ethnic or linguistic identity to the detriment of electors' other 
interests, while also having the possible effect of MLAs from such districts not being seen as full and legitimate members of the Assembly (86).

\section{American Majority-Minority Districts}

Nova Scotia's protected ridings bear a somewhat closer resemblance to the American concept of 'Majority-Minority' districts. In various parts of the United States, legislators have made conscious efforts when creating electoral districts to ensure that in some districts, ethnic minorities, generally Latino or African Americans, will make up a majority of electors. The practice has been encouraged by the US Justice Department, though it has received some criticism from the Supreme Court, particularly where it created especially irregular boundary lines (Banducci, Donovan, and Karp 2004: 535). They have been often recognized as being effective in increasing the number of Black and Latino members of Congress, though some have raised doubts as to their overall effectiveness on advancing minority interests (Cameron, Epstein, and O’Halloran 1996).

While quite similar, protected ridings differed from majority-minority districts in two key aspects. Firstly, whereas the two of the three Acadian ridings were indeed majority Acadian, even at the time of its creation Preston's population had only a 'Black population concentration between 25 to 35 percent of the total constituency', (Landes 1992: 29) and Richmond's Francophone population made up a similar proportion of that riding (Statistics Canada 2012). For demographic reasons, however, this difference is somewhat inevitable, as Nova Scotia's very white and anglophone population does not make it particularly easy to carve out true majority-minority districts. Secondly, as with the New Zealand system, Nova Scotia differs in allowing the protected ridings to have populations far under the provincial average, even outside of normally permitted variations. The protected ridings are, however, similar to the majority-minority districts in that they seem to encourage a form of surrogate representation to those members of the minority group who live outside of the district. They also share the same difference from New Zealand in that their representatives do not solely represent the minority group of interest, but also many majority group constituents as well.

\section{Surrogates by design}

The three boundaries commissions that have addressed the issue of protected ridings devoted relatively little effort to explaining their conception of representation. As Bickerton and Graham (2020) argue, the decision to use protected ridings (or 'consociational districting') to achieve this goal of minority representation was largely a product of path dependency, building off of existing districts and retaining the existing electoral system. While I do support my argument using the reports of various boundaries commissions and arguments made by legislators, it is not my contention that the Commissions consciously or intentionally created a system which would institutionalise surrogate representation. Rather, I contend that their efforts to improve minority representation in the House resulted in a system of institutionalised surrogates.

Nevertheless, the writings and decisions of the commissions reveal much about how these districts aid in representing the broader Acadian and African Nova Scotian communities. As the 'protected 
riding' concept was then new, the 1992 Commission devoted some effort to explaining the idea and its implementation in their final report:

The Provincial Electoral Boundaries Commission concluded that [protected ridings] was the best method for encouraging the effective representation of such groups in the Nova Scotia House of Assembly. Thus, there are no specifically-designated Acadian seats, nor is there a specifically-designated Black seat. Instead, boundary lines are recommended that encourage, but do not guarantee, minority group representatives in the House of Assembly (Landes 1992: 28).

Of particular note in this definition is that the Commission makes no particular effort to represent the communities themselves in which the MLAs would sit. That is to say, the emphasis was not on ensuring that such communities as Clare or Argyle were represented as cohesive units in the House, but only to encourage the election of more Acadian and Black MLAs. The 'communities of interest' that justify deviating from the norms of electoral parity were the Acadian and African Nova Scotian populations of the province as a whole, rather than the specific four communities within the boundaries of the protected ridings.

The logic used to explain the creation of the riding of Preston illustrates this even more clearly - the commission is quite candid in revealing that they first decided to create a riding to favour the representation of African Nova Scotians, and later decided that Preston would be an appropriate location for such a riding (Landes 1992: 28-29). Thus, the justification for Preston's deviation from the usual population size of districts relates not to the needs of the entire African Nova Scotian community, rather than specifically to those who reside in Preston.

It is worth noting that the goal of the Commissions seemed to follow a logic of descriptive representation, and their aim was to increase number of Acadian and African Nova Scotian members in the House of Assembly to more closely reflect their number in the population. Nonetheless, the method through which they chose to do so was also form of surrogate representation. As the case of Preston best illustrates, the concern of the Commission was not to represent the specific communities of the protected ridings, but rather the entire Acadian and Black populations of the province. By creating a system with the goal of installing representatives for a community with whom they would have no direct electoral link, Nova Scotia effectively institutionalised surrogate representation for its Black and Acadian communities. Therefore, at least in the case of Nova Scotia's protected ridings, surrogate representation is not a completely ad-hoc phenomenon that arises to fulfill the shortcomings of a single member plurality electoral system, nor is it the circumstantial by-product of a programme to represent specific geographic communities. Rather, it was the explicit design of the Commission to create a system that favoured the creation of dedicated surrogate representatives.

While the 1992 commission devoted the most attention in their writings to the protected ridings, later commissions did also review the concept. The 2002 Boundaries Commission devoted relatively little attention to the notion of representation in recommending retaining unchanged the districts of Argyle, Clare, Preston and Richmond, which it referred to as 'constituencies for minority 
representation' (Dodds 2002: 37). The commission did, however, express some reservations, seemingly on the basis that the protected constituencies ${ }^{6}$ small size causes other ridings to be underrepresented, and thus recommended 'that this method of encouraging minority representation should be re-evaluated during the next electoral redistribution' (Dodds 2002: 37). Their hesitancy regarding the system, however, seemed only to be based on some objections expressed regarding voter parity during the public consultations, and not on an objection to the surrogate model itself.

Although the 2012 commission did ultimately recommend the abolition the protected ridings, they still seemed to believe in strongly in the concept. Commission member James Bickerton said in an interview that "in our best judgment, retaining the protected ridings was really the only way of safeguarding Acadian representation and African Nova Scotian representation in the House of Assembly." (Medel 2012) The reason then for their abolition was that the terms of reference provided to them by the government stipulated that even for reasons of minority representation ridings could not deviate from the average size by over $25 \%$ ('Report of the Select Committee on Establishing an Electoral Boundaries Commission’ 2011: 8). The sole Acadian member of the commission even resigned in protest, stating 'my conscience and my judgment will not allow me to recommend the elimination of the protected constituencies' (Gaudet 2012: 13).

This firm belief in the need for Acadian and African Nova Scotian representation coupled with the strict terms of reference compelled the committee to consider, though not formally recommend, more creative solutions. Based upon a proposal presented at a public consultation, the commission considered a New Zealand-style solution wherein the province would be divided into several Acadian seats that would overlap the other ridings, with voters being able to vote for either (MacNeil 2012: 18-19). They also proposed as an alternative allowing a single such seat to be created, for which Acadians could vote in addition to their traditional geographic MLA - they justified the disparity in voter parity as being a form of 'political insurance' for Acadians' and that 'it would recognize the shared cultural and linguistic concerns of all Acadians and minority Frenchspeakers, regardless of where they live in the province', as well as recognizing the importance of the Acadian people historically (MacNeil 2012: 20).

In their report, which recommended the re-establishment of all four 'exceptional districts' as they referred to them, the 2019 Commission explained the role of these representatives the most succinctly: 'Those MLAs who represent exceptional electoral districts are expected to take on the dual role of representing and protecting the interests and identities of Acadians and African Nova Scotians in their own electoral districts as well as those belonging to these cultural communities wherever they live in the province' (Dodds 2019: 89). While the details of these districts have varied throughout their existence, their purpose has been to use electoral districts in aeras with more concentrated minority populations in order to achieve surrogate representation throughout the province.

\section{Representation for all Acadians and African Nova Scotians?}

Given that many of the citizens which they were intended to represent resided outside of their boundaries, the protected ridings have an apparent shortcoming in their democratic accountability; 
many members of the community of interest have no way to influence the selection of their 'representative', and as such there it is not clear how their interests would be considered. In this section, I will use excerpts from debates in the House of Assembly to explore two ways in which an indirect link could be conceptualised between a protected riding MLA and the broader membership of the community of interest their riding was intended to serve.

Being the product of an uncontroversial non-partisan Boundaries Commission, the original implementation of the protected ridings system provoked no substantial debate in the House of Assembly. The decision to abolish the protected ridings, by contrast, was rather controversial and was publicly opposed by opposition parties. The resultant debates in the House of Assembly and in provincial news media reveal that understanding of the surrogate role of the protected ridings' MLAs was widespread, and further that two distinct models of this surrogate role were in use.

In debating Bill 94, which implemented the 2012 Commission's recommendation to merge the protected ridings, Richmond MLA Michel Samson made it very clear that he and his Acadian colleagues were surrogate representatives. He drew upon the opinions of residents of Pomquet, an Acadian community in majority-Anglophone Antigonish County, who argued that - the member for Richmond, the member for Argyle, the member for Clare don't just represent Acadians in their constituencies, they represent all of us, throughout Nova Scotia. They are our voice in the Legislature. Even though the member is from Richmond, he speaks for Acadians in Pomquet...' (Nova Scotia 2012: 2618). Samson had at other times expressed that he shared this perception of his role as MLA, saying 'nous, députés acadiens, savons que nous sommes responsables à la population acadienne qui nous a élus’ (Michel Samson, as quoted in Landry 2012).

Despite being fiercely opposed to the merger of the protected ridings in with their majority white and anglophone neighbours, members of both the official opposition Liberal Party and third-party Progressive Conservatives did not substantially differ from the government in their views on how the protected ridings functioned. Liberal leader Stephen McNeil described what he viewed as the success of the protected ridings, saying: 'they've seen what has happened with their voices at the Cabinet Table - someone who is representing their linguistic and cultural differences, Mr. Speaker, someone who is protecting minority rights in the Province of Nova Scotia, they wanted those rights protected... Mr. Speaker, Acadian communities across this province were represented well in this House by their protected ridings and by the members who represented them' (Nova Scotia 2012: 5090).

McNeil's comments, which are generally representative of the comments made by other members of the opposition, demonstrate that for him too the matter of importance was having members of minority groups present in the making of government decisions to ensure that their particular interests are taken into consideration. Although obviously only some Acadians have any influence over the selection of the members who represent the protected ridings, Acadians everywhere can benefit from having their voices in the House of Assembly protecting their rights. In this McNeil 
appear to also firmly believe that the Acadian MLAs were surrogate representatives, and that they were also effective ones.

The ambiguity in McNeil's last sentence does however show that is conception could differ somewhat from that expressed by the government. In referring to how all Acadians are represented (presumably via a surrogate form of representation), he specifies that they are represented by the members elected from protected constituencies, rather than specify that they are represented those MLAs who are Acadian.

McNeil's lack of emphasis on the minority-status of the MLAs themselves was made far more explicit by other members of the opposition. In defending the effectiveness of the Preston riding despite it generally having elected a white representative, MLA Andrew Younger said: 'the former NDP MLA for Preston ... knows that at the moment Preston isn't represented by someone whose skin colour is black, but she still felt that was important because she recognizes that it's not about the person' (Nova Scotia 2012: 5087). Thus, whereas most others seem to make the assumption that the goal of the protected ridings is to elect MLAs who are themselves Acadian or African Nova Scotian (or presumably of another group were Nova Scotia's demographics different) so that they may represent the broader interests of their community, at least some insist that the protected ridings can still protect minority interests even under majority-group MLAs.

Michel Samson, MLA for Richmond extended this philosophy to his own Acadian riding, saying that 'to suggest today that Preston is not working is to say that Richmond didn't work from 1993 to 1998 because it didn't have an Acadian representing it. That is offensive to me, it is offensive to the people of Richmond County, just as it should be offensive and it is offensive to the people of Preston to make that type of suggestion' (Nova Scotia 2012: 2612). Assuming that Samson and Younger share the same definition of what it is for the protected ridings to work as did the boundaries commissions and the Dexter government - that is to say that their goal is to represent the interests of Acadians and African Nova Scotians throughout the province - then it is clear that in their view that the election of minority, or in other terms descriptive, MLAs is not a necessary component of the model of surrogate representation that underlies the protected ridings system.

While those in government and in opposition broadly agreed that the Acadian and African Nova Scotian communities benefited from an increased form of surrogate representation under the protected ridings system, the government disputed the degree to which it was functioning, necessary, or justifiable. Nevertheless, opinions differed regarding how that surrogate representation was achieved. For most, the system worked as follows: by allowing certain ridings to have much smaller than average populations it is possible to achieve a significant concentration of a particular minority group within this riding. Presuming that minority electors will be more likely to vote for a member of their own minority group, this increases the odds that a member of that group will end up being elected to the House of Assembly. As they share and understand the interests and experiences of members of their group, these minority MLAs will advocate for issues pertinent to members of their group and argue against any proposal that may hurt their interests. Thus, by electing minority-group 
MLAs in these protected ridings, it is possible to ensure that the interests of that members of that group throughout the province are represented in the legislature. Although minority-group citizens from outside of the district will not have an electoral relationship with these MLAs, their shared identity is presumed to ensure that their interests will nevertheless be represented.

The second conception agrees on the basis of the system but differs in how it translates the opinions of the minority group into legislative action. While the point of permitting smaller ridings is still to allow a greater concentration of the minority group of interest than would otherwise be possible, it is not actually important that they elect members of their own ethnic or linguistic group to the House of Assembly. Rather, as the minority electors in question constitute a decisive voting bloc in this protected riding, any MLA elected (or who hopes to be elected) will need to be particularly mindful of the interests of this group in order to win and maintain their office. As the minoritygroup constituents in the protected riding share common interests with their fellow minority-group members throughout the province, the MLA for a protected riding will also take stances in the legislature that benefit members of the minority group of interest throughout the province, thus ensuring their effective representation.

In sum, the first (more commonly mentioned) model relies on the ethnic or linguistic identity of the MLA of the protected riding to inform their decision making in a fashion that will benefit the minority-group in question. Here a surrogate relationship exists between the representative and the other members of their minority, with the expectation that they will represent their interests by virtue of sharing their identity. The second model rather relies on the electoral relationship and a model of either promissory or anticipatory representation between the constituents of the protected riding and their MLA in order to represent the minority group's interest. In this second model, the surrogate relationship effectively exists between those members of the community of interest resident in the protected riding and those who reside elsewhere; they are expected to share the interests of other members of their minority group, and to ensure representation of those interests via their electoral relationship with their representative.

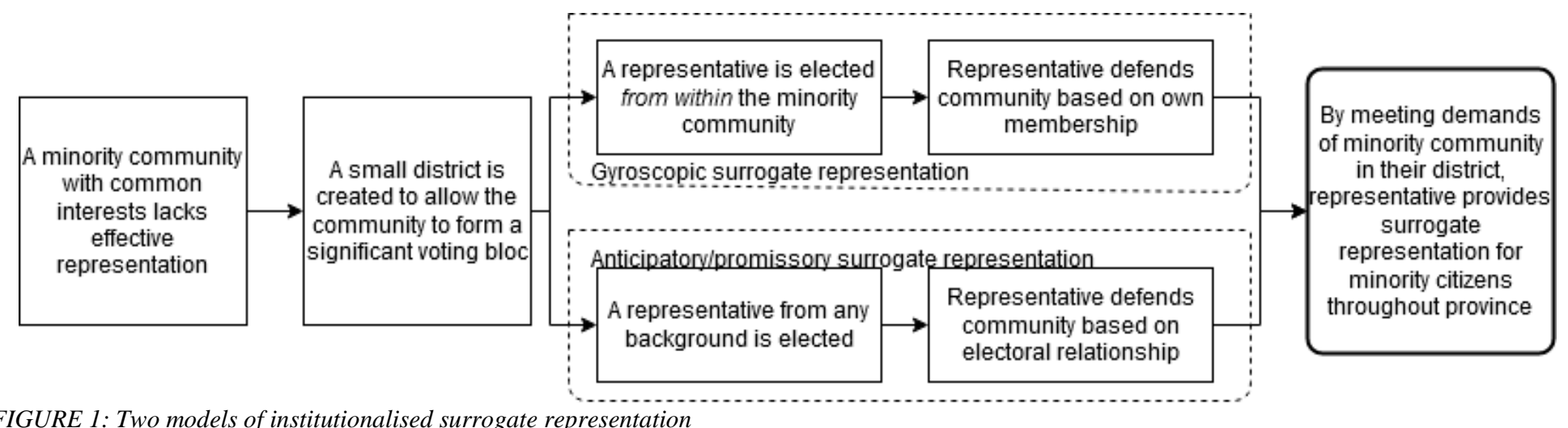

FIGURE 1: Two models of institutionalised surrogate representation

As I have established, these two models use different means to arrive at the same end of surrogate representation for those African Nova Scotians and Acadians who live outside of the protected 
ridings. The version of representation that exists between the residents of the protected riding and their MLA does however differ between the models. As previously stated, the relationship that exists between the MLA (of a possibly different ethno-linguistic group) and their minority-group constituents in model two is presumably either promissory or anticipatory under Mansbridge's typology (2003). Under the traditional promissory conception, the MLA would make promises to please their minority constituents at the time of their election, and then follow through on those promises throughout their term in office. Under an anticipatory model, the MLA would spend their time in office anticipating how their minority constituents will view their actions come election time and proceeded accordingly to ensure their re-election. Whichever (or whatever combination) of these two models is used to explain the relationship between the representative and their constituents, the crux of the issue is that model two presumes that the protected riding's MLA will be attentive to the needs of their minority constituents, and thus fulfill the needs of members of this group throughout the province.

The first model, however, assumes a somewhat different relationship between representative and constituents. Although naturally an Acadian or African Nova Scotian MLA in a protected riding will still make promises and worry about re-election, the logic that lead to the creation of these ridings nevertheless seems to very closely reflect what Mansbridge calls 'gyroscopic representation'. According to Mansbridge, under this model 'voters select representatives who can be expected to act in ways the voter approves without external incentives. The representatives act like gyroscopes, rotating on their own axes, maintaining a certain direction, pursuing certain built-in (although not fully immutable) goals' (Mansbridge 2003: 520). To return to the 1992 Boundaries Commission, the expressed aim in was to create a smaller than average district with a majority (or large minority) of a certain minority group so as to 'encourage, though not guarantee, minority group representatives in the House of Assembly' (Landes 1992: 28). In this conception, it is therefore assumed that the Acadian and African Nova Scotian voters of the protected ridings would tend to elect Acadians and African Nova Scotians to the House of Assembly. In so doing, they would be essentially setting in motion a gyroscope, that would of its own momentum and without the need of electoral pressure from its constituents serve the interests of the minority group in question around the province.

The MLA elected under the first model would therefore be a form of 'gyroscopic surrogate', set in motion by their protected riding constituents to protect the interests of the minority group in question throughout the province. In so doing, 'the representatives act only for 'internal' reasons' (Mansbridge 2003: 520) namely for the desire to protect their own culture and their own affinity for other members of their groups. The MLA in model two would by contrast be a 'promissory/anticipatory surrogate'; they gain and keep their office by conforming to the desires of their minority-group constituents. Because these constituents share interests with their fellow minority-group citizens throughout the province, and because their wishes may include a broader desire to see the interests of their group protected throughout the province, this electoral relationship in the protected riding confers a surrogate relationship on those outside of it. 
Common to both models, however, is an underlying assumption that the interests of the minority group (be they Acadians, or African Nova Scotians, or another group) are fairly universal. In the first model it is assumed that simply by belonging to a given minority group that an MLA will sufficiently understand that group's needs and interests, and hold a sufficient feeling of duty to those with whom they share an identity to provide them with more effective representation. This could be understood to happen due to minority members of the House being better able to relate to other members of their own minority group and better able to understand their points of view, or due to minority MLAs standing up for their own personal interests, which are assumed to naturally coincide with other members of their minority group. In the second model, it is assumed that by meeting the needs of the minority residents of a protected riding that an MLA will necessarily also meet the needs of those who live elsewhere in the province. Presumably, these minority group constituents in the protected riding will bring their problems and concerns to their MLA (regardless of his or her linguistic or ethnic identity) and their MLA will in turn represent these concerns in the House of Assembly. As the concerns presented by their constituents in the protected riding are presumed to coincide with the concerned of members of the minority group of interest throughout the province, the minority group members outside the riding are represented as well.

Both of these models then will prove far more effective if the underlying assumption of a homogenous minority group of interest is correct. If the African Nova Scotian residents of New Glasgow or North-End Halifax happen to in fact have different identity-based interests they wish to be addressed in the House then do their counterparts in Preston, or if the urban Acadian population of Halifax has different grievances with the government than do the rural Acadians in the protected ridings, then neither model of surrogate representation presented above can prove effective. The gyroscopic surrogate however may still prove effective, provided that electors in the protected riding select a gyroscope that also understands and is concerned with issues around the province. This however would be a happenstantial by-product of the protected riding, and not part of its design.

It is worth restating here that this second model of surrogate representation does not appear to have guided the creation of the protected ridings. While it may nevertheless be a valid interpretation of how these ridings protected minority interests under majority-group MLAs, in reading the relevant sections of the report of the 1992 Boundaries Commission it becomes quite apparent that their goal was to encourage representatives (i.e. MLAs) who were themselves members of a minority-group, and not simply to ensure that the groups' interests were represented. Nevertheless, in the eyes of at least some, the framework they created gave rise to a rather unusual non-descriptive form of surrogate representation, wherein the representative has a non-gyroscopic motivation to serve as a surrogate.

\section{Conclusion}

The Nova-Scotian experiment of Protected Ridings are a unique project for minority representation and present an unusual model of the relationship between representative and constituent. These districts differ from similar projects in New Zealand and the United States by having no direct link between many in the represented community of interest and their elected representative, and by the 
districts to be significantly smaller in population than those elsewhere in the province. Furthermore, as they were created to address a province-wide issue of underrepresentation, the idea that legislators elected in these districts would serve as surrogate representatives for electors elsewhere in the province is implicit in their design. As such, I argue that these Protected Ridings provide surrogate representation through their very structure, thus demonstrating that surrogate representation is not purely an ad-hoc phenomenon.

Supported by parliamentary debates, I further argue that a surrogate representative for a minority group does not inherently need not to be a descriptive representative and argue that this reveals two distinct models of surrogate representation, which I categorise as 'promissory/anticipatory surrogate representation' and 'gyroscopic surrogate representation'. By faithfully representing the minority electors in their own district, a majority-group representative can become a surrogate representative for those elsewhere.

Finally, my analysis has significant implications for policy; while Nova Scotia will essentially be returning to the use of 'protected ridings' or 'exceptional districts' as of its next general elections (expected for 2021), future efforts to increase minority representation, in Nova Scotia or elsewhere, would be well served to critically reflect upon this example. While any proposal to change the workings of elections requires a careful balance of principles and interests, the question of how increased representation will work in practice should also be carefully considered - does effective representation require that minority electors have a direct relationship with their representatives? Further study of the Nova Scotian case could provide a fruitful example for examining the necessity of a direct link between citizens and legislators in improving representation for under-represented groups.

\section{Notes}

1. Although legislation generally refers to 'electoral districts', 'riding' is the term generally used by to denote the aera represented by a legislator in Nova Scotia.

2. Although the 1992 commission uses the term 'Black', African Nova Scotian is the term used in the vast majority of 21 st century government documents to refer to residents of African descent. In this article I use the terms interchangeably, in function with the source material.

3. The 1992 commission also protected a fifth riding, Victoria, due to its vast size and highly rural character.

4. Although there exists no such institution as the Legislative Assembly, the initialism MLA is nonetheless far more popular than MHA, and is widely used by the government itself

5. For a thorough history of the creation, abolition, and re-creation of the protected ridings, see Bickerton and Graham (2020). 
6. The 2002 Commission did explicitly reject this term, opting instead to refer to the 'extraordinary circumstances clause' contained in their terms of reference. I use the terms interchangeably nonetheless as it accurately describes their seat allocation process, which does not substantively differ from that used in 1992.

\section{References}

Banducci, Susan A., Todd Donovan, and Jeffrey A. Karp, 2004, 'Minority Representation, Empowerment, and Participation', Journal of Politics 66:2, 534-56, https://doi.org/10.1111/j.1468-2508.2004.00163.x.

Bickerton, Jim, and Glenn Graham, 2020, 'Electoral Parity or Protecting Minorities? Path Dependency and Consociational Districting in Nova Scotia', Canadian Political Science Review 14:1, 32-54.

Cameron, Charles, David Epstein, and Sharyn O'Halloran, 1996, 'Do Majority-Minority Districts Maximize Substantive Black Representation in Congress?' American Political Science Review 90:4, 794-812, https://doi.org/10.2307/2945843.

Deschênes-Thériault, Guillaume, 2018, 'Le système électoral et la représentation politique de la minorité acadienne en Nouvelle-Écosse', Thesis, University of Ottawa, https://doi.org/10.20381/ruor-22755.

Dodds, J. Colin, and The Electoral Boundaries Commission, 2002, 'Just Boundaries:

Recommendations for Effective Representation for the People of Nova Scotia', Provincial Electoral Boundaries Commission, https://nselectoralboundaries.ca/sites/default/files/electoral_boundaries_2019_english_we b.pdf.

---, 'Balancing effective representation with voter parity', Provincial Electoral Boundaries Commission, http://0-nsleg-edeposit.gov.ns.ca.legcat.gov.ns.ca/deposit/b10097223.pdf.

Executive Council of Nova Scotia, 1991, Order-in-Council 91-844, http://www.novascotia.ca/exec_council/oic/view.asp?oicID=314.

Fleras, Augie, 1985, 'From Social Control towards Political Self-Determination? Maori Seats and the Politics of Separate Maori Representation in New Zealand'. Canadian Journal of Political Science 18:3, 551-576, https://doi.org/10.1017/S0008423900032455.

Gaudet, Paul, 2012, 'Dissenting Member of the Commission', in The Electoral Boundaries Commission and Teresa MacNeil, Toward Fair and Effective Representation, http://0-nslegedeposit.gov.ns.ca.legcat.gov.ns.ca/deposit/b10653107.pdf.

Geddis, Andrew, 2006, 'A Dual Track Democracy? The Symbolic Role of the Maori Seats in New Zealand's Electoral System', Election Law Journal 5:4, 347-371.

Hyson, Stewart, 1995, 'The Electoral Boundary Revolution in the Maritime Provinces', The American Review of Canadian Studies 25:2/3, 285-295.

Keefe, Douglas and The Commission on Effective Electoral Representation of Acadian and African Nova Scotians, 2017, 'Representation: Toward More Effective Representation for Acadian and African Nova Scotians', https://novascotia.ca/representation/Representation-TowardMore-Effective-Representation-For-Acadian-and-African-Nova-Scotians-Report-andRecommendation.pdf

Landes, Ronald G., and The Provincial Electoral Boundaries Commission, 1992, 'Effective Political Representation in Nova Scotia: The 1992 Report of the Provincial Electoral Boundaries Commission'.

Landry, Richard, 2012, 'Circonscriptions Électorales Des Régions Acadiennes : Les Trois Députés Acadiens s'expriment', Le Courrier de La Nouvelle-Écosse, 24 February 2012. 
MacNeil, Teresa and The Electoral Boundaries Commission, 2012, 'Toward Fair and Effective Representation', http://0-nsleg-edeposit.gov.ns.ca.legcat.gov.ns.ca/deposit/b10653107.pdf.

Mansbridge, Jane, 1999, 'Should Blacks Represent Blacks and Women Represent Women? A Contingent "Yes"', The Journal of Politics 61:3, 628-657. https://doi.org/10.2307/2647821.

---, 2003, 'Rethinking Representation', American Political Science Review 97:4, 515-28, https://doi.org/10.1017.S0003055403000856.

---, 2011, 'Clarifying the Concept of Representation', American Political Science Review 105:3, 621-630, https://doi.org/10.1017/S0003055411000189.

Medel, Brian, 2012, 'Electoral Board Feared Consequences of Resigning; Members Worried Replacement Would Be "less Sympathetic" to Smaller Communities', The Chronicle-Herald, 16 August 2012.

Nova Scotia, 2012, 'Hansard: Debates and Proceedings', The Nova Scotia Legislature, http://nslegislature.ca/index.php/proceedings/hansard/C89/house_12dec06/.

Reference re Prov. Electoral Boundaries (Sask.), 1991, 2 SCR 158, SCC.

Reference re the Final Report of the Electoral Boundaries Commission, 2017 10, NSCA.

'Report of the Select Committee on Establishing an Electoral Boundaries Commission', 2011, http://nslegislature.ca/pdfs/committees/el/FinalReport.pdf.

Statistics Canada, 2012, '2011 Census of Canada: Topic-Based Tabulations - Detailed Mother Tongue', http://www12.statcan.ca/census-recensement/2011/dp-pd/tbt-tt/Rpeng.cfm?TABID $=2 \& L A N G=E \& A P A T H=5 \& D E T A I L=0 \& D I M=0 \& F L=A \& F R E E=0 \&$ $\mathrm{GC}=12 \& \mathrm{GK}=1 \& \mathrm{GRP}=0 \& \mathrm{PID}=103251 \& \mathrm{PRID}=0 \& \mathrm{PTYPE}=101955 \& \mathrm{~S}=0 \& \mathrm{SHOWALL}$ $=0 \& S U B=0 \&$ Temporal $=2011 \&$ THEME $=90 \& V I D=0 \& V N A M E E=\& V N A M E F=$.

---, 2015, '2011 National Household Survey: Data Tables - Visible Minority Status', http:/ /www12.statcan.ca/nhs-enm/2011/dp-pd/dt-td/Rpeng.cfm?LANG $=\mathrm{E} \& A P A T H=5 \& D E T A I L=0 \& D I M=0 \& F L=A \& F R E E=0 \& G C=12 \& G I$ $\mathrm{D}=0 \& \mathrm{GK}=1 \& \mathrm{GRP}=0 \& \mathrm{PID}=105395 \& \mathrm{PRID}=0 \& \mathrm{PTYPE}=105277 \& \mathrm{~S}=0 \& \mathrm{SHOWALL}=0$ $\& S U B=0 \&$ Temporal $=2013 \&$ THEME $=95 \& \mathrm{VID}=0 \& \mathrm{VNAMEE}=\& \mathrm{VNAMEF}=$.

Tremblay, Manon, 2006, 'The Substantive Representation of Women and PR: Some Reflections on the Role of Surrogate Representation and Critical Mass', Politics \& Gender, 2:4 (December), 502-511. https://doi.org/10.1017/S1743923X06231143.

Vowles, Jack, 2005, 'New Zealand: The Consolidation of Reform?' in Michael Gallagher and Paul Mitchell (eds.), The Politics of Electoral Systems (Oxford: Oxford University Press), pp. 295-312. 